\title{
Correction to: Bioengineering potato plants to produce benzylglucosinolate for improved broad-spectrum pest and disease resistance
}

\author{
M. E. González-Romero - C. Rivera - K. Cancino - F. Geu-Flores • \\ E. G. Cosio $\cdot$ M. Ghislain $\cdot$ B. A. Halkier $\mathbb{C}$
}

Accepted: 20 May 2021 / Published online: 14 June 2021

(C) The Author(s) 2021

Correction to: Transgenic Res https://doi.org/10. 1007/s11248-021-00255-w

In the above mentioned publication, a third affiliation was erroneously indicated for M. E. González-Romero where it should have been two. The original article has been corrected and the correct affiliations are also published here.

The article Bioengineering potato plants to produce benzylglucosinolate for improved broad-spectrum pest and disease resistance, written by $\mathrm{M}$. E. González-Romero, C. Rivera, K. Cancino, F.

The original article can be found online at https:// doi.org/10.1007/s11248-021-00255-w.

M. E. González-Romero · C. Rivera ·

K. Cancino · M. Ghislain ( ()

Applied Biotechnology Laboratory, International Potato

Centre, P.O. Box 1558, Lima 12, Peru

e-mail: m.ghislain@cgiar.org

M. E. González-Romero · B. A. Halkier ( $ه)$

Department of Plant and Environmental Sciences,

DynaMo Center, University of Copenhagen,

Thorvaldsensvej 40, 1871 Frederiksberg, Denmark

e-mail: bah@plen.ku.dk

Present Address:

C. Rivera

Universidad Nacional Agraria La Molina, Av. La Molina s/n, Lima 12, Peru
Geu-Flores, E. G. Cosio, M. Ghislain and B. A. Halkier, was originally published electronically on the publisher's internet portal on 06 May 2021 without open access. With the author(s)' decision to opt for Open Choice the copyright of the article changed on 19 May 2021 to (C) The Author(s) 2021 and the article is forthwith distributed under a Creative Commons Attribution 4.0 International License, which permits use, sharing, adaptation, distribution and reproduction in any medium or format, as long as you give appropriate credit to the original author(s) and the source, provide a link to the Creative Commons licence, and indicate if changes were made.

The images or other third party material in this article are included in the article's Creative Commons

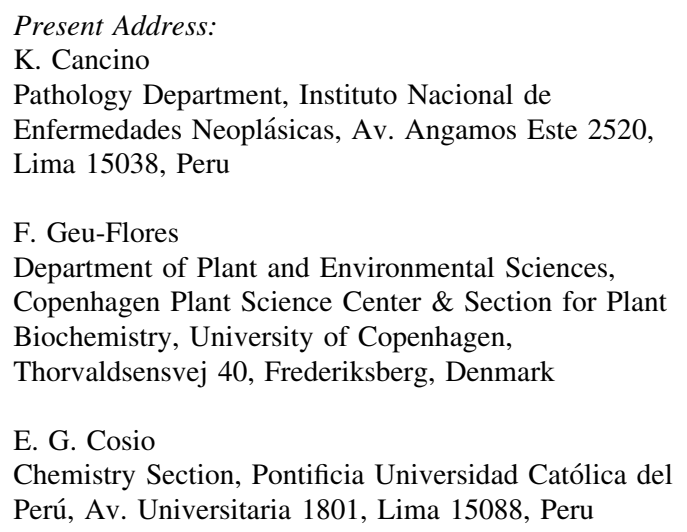


licence, unless indicated otherwise in a credit line to the material. If material is not included in the article's Creative Commons licence and your intended use is not permitted by statutory regulation or exceeds the permitted use, you will need to obtain permission directly from the copyright holder.

To view a copy of this licence, visit http:// creativecommons.org/licenses/by/4.0/.

Open Access This article is licensed under a Creative Commons Attribution 4.0 International License, which permits use, sharing, adaptation, distribution and reproduction in any medium or format, as long as you give appropriate credit to the original author(s) and the source, provide a link to the Creative Commons licence, and indicate if changes were made. The images or other third party material in this article are included in the article's Creative Commons licence, unless indicated otherwise in a credit line to the material. If material is not included in the article's Creative Commons licence and your intended use is not permitted by statutory regulation or exceeds the permitted use, you will need to obtain permission directly from the copyright holder. To view a copy of this licence, visit http://creativecommons.org/licenses/by/4.0/.

Publisher's Note Springer Nature remains neutral with regard to jurisdictional claims in published maps and institutional affiliations. 